\title{
The human side of social technology for climate change mitigation and human development: the case of 'efficient stoves' in Brazil
}

\author{
Andréa Cardoso Ventura
}

Luz Fernandez

José Célio Silveira Andrade

\author{
Julio Lumbreras Martín
}

\begin{abstract}
Carbon management has gradually gained attention within the overall environmental management and corporate social responsibility agendas. The clean development mechanism, from Kyoto Protocol, was envisioned as connecting carbon market and sustainable development objectives in developing countries. Previous research has shown that this potential is rarely being achieved. The paper explores how the incorporation of the human side into carbon management reinforces its contribution to generate human development in local communities and to improve the company's image. A case study of a Brazilian company is presented, with the results of the application of an analytical model that incorporates the human side and human development. The selected project is an 'efficient stoves' programme. 'Efficient stoves' are recognised in Brazil as social technologies. Results
\end{abstract}


suggest that the fact that social technologies value the human side of the technology plays a key role when it comes to analysing the co-benefits of the project implementation.

Keywords: social technologies; climate change; human development; carbon market; technology human side; Brazil.

Reference to this paper should be made as follows: Ventura, A.C., Fernandez, L., Andrade, J.C.S. and Martín, J.L. (2012) 'The human side of social technology for climate change mitigation and human development: the case of 'efficient stoves' in Brazil', Int. J. Environment and Sustainable Development, Vol. 11, No. 4, pp.375-393.

Biographical notes: Andréa Cardoso Ventura is a $\mathrm{PhD}$ student in Administration at Federal University of Bahia (UFBA) - Brazil. She received her Master in Administration in 2008 from UFBA, and in Estudios Contemporâneos de América Latina from Universidad Complutense de Madrid (UCM). Her fields of research: global environmental governance; social and environmental conflicts, clean development mechanism - CDM project and social technologies.

Luz Fernandez is a $\mathrm{PhD}$ student in Environmental Engineering from the Technical University of Madrid (UPM). She received her Master in Environment and Development in 2008 from King's College University of London. Her fields of research are on carbon projects and human development. She has professional experience working with environmental international cooperation projects in the Dominican Republic and Haiti.

José Célio Silveira Andrade is a $\mathrm{PhD}$ in Administration. Professor at Federal University of Bahia (UFBA) - Brazil. He is a Coordinator of the 'Environmental Global Governance and Clean Development Mechanism Research Group' at UFBA. His fields of research: international environmental regimes; global environmental governance; environmental management and international relations; world carbon market and corporate strategies; clean development mechanism - CDM project, cleaner technologies and sustainable development.

Julio Lumbreras Martín is a Chemical and Environmental Engineer. He received his $\mathrm{PhD}$ on Air Quality at the Technical University of Madrid in 2003. Currently, he is Lecturer and Vice-Dean at the School of Industrial Engineering within the Technical University of Madrid (UPM). He is a 'Honorary Research Fellow' at Birmingham University (UK). He is the Spanish Representative at the Task Force on Integrated Assessment Modelling within the UN Convention on Long-Range Transboundary Air Pollution (CLRTAP). His fields of research: urban air quality; integrated assessment modelling; impacts of carbon projects on human development

\section{Introduction}

Global environmental initiatives create macro-level agreements, but the true test is how local communities respond to such agreements. The clean development mechanism (CDM), created by the Kyoto Protocol, was envisioned as a mechanism that would connect the carbon market and sustainable development objectives in developing 
countries. According to NGOs, CDM has to retain its integrity in order to remain an important mechanism that satisfies these dual purposes for which it has been designed (Umamaheswaran and Michaelowa, 2006). This integrity is directly linked with the use of more efficient technologies. Previous works have shown that CDM has been a ground-breaking success creating a dynamic carbon market while there is a large room to improve it (Boyd et al., 2009). Specifically, concerning the existing procedure for CDM registration, the determination of additionally is the main drawback (Schneider, 2008). Regarding its outcome, the lack of contribution to sustainable development seems to be the main challenge (Olsen, 2007; Subbarao and Lloyd, 2011).

Parallel with the CDM market, a voluntary market for carbon offsets has emerged. The voluntary market consists of companies, governments, organisations, organisers of international events, and individuals, taking responsibility for their carbon emissions by voluntarily purchasing carbon offsets. Far from the stringent CDM guidelines (i.e., lengthy paper work, and high transaction costs), voluntary carbon markets are expected to have a higher contribution to sustainable development (Chapple, 2008; Kollmuss et al., 2008; Muller, 2008; Nussbaumer, 2009).

Climate change and 'carbon management' has gradually gained prominence within the overall environmental management (EM) and the corporate social responsibility (CRS) agendas of corporations. Demonstrating a commitment to reducing carbon emissions and purchasing offsets is a way for firms to boost their 'green' image as an environmentally responsible company. Purchasing offsets with 'development benefits' can be particularly important in this context as they can be marketed as charitable, poverty alleviating investments as well. Another important factor influencing the purchase of offsets is the ability to defend a 'business case' for carbon neutrality or reduction and high level commitment from senior management (Tayab, 2006). Although offsetting or going carbon neutral have not yet been widely adopted by companies, an increase in knowledge and information on the available options could transform offsetting into a popular trend or could integrate it as a key component of CRS and $\mathrm{EM}$.

In this backdrop, this paper discusses the incorporation of the human factor and/or human side into carbon management, highlighting its contribution to both generating human development in the local communities and improving the company's image. It is important to note, that there are many human development co-benefits from investment in climate change mitigation projects channelled through the carbon markets towards developing countries, including technology and know-how transfer. The investigation has been carried out analysing a type of technology with a clear human perspective: social technologies (ST). A case study from an offsetting project implemented by a leading Brazilian company in EM activities is presented. The major contribution from this article is to discuss if ST, by adding a human side to technology, could present a good alternative to combat the climate change while contributing to human development.

This paper is structured as follows. Section 2 provides an overview of the current debate on carbon markets and human development. Section 3 introduces the conceptual and theoretical basis for ST and its role within the carbon markets and mitigation potential in the state of Bahia, Brazil. Section 4 discusses a theoretical framework for the analysis while Section 5 introduces the case study and presents the results of the theoretical framework application. Finally, Section 6 summarises the major arguments in this paper and suggests further areas of research. 


\section{Carbon markets and human development}

Although carbon offset markets (compensatory and voluntary) are growing rapidly, many critics have questioned their contributions to development, particularly in terms of providing human development for local communities.

The Carbon Management and Offsetting Trends Survey Results 2009 (Ashford et al., 2009) found that the key factor for buyers in choosing the right carbon credit is the ability of projects to generate local community benefits $(\mathbf{5 5 \%}$ of respondents rated this factor as highly important). However, this apparent tendency towards development benefits through carbon markets does not reflect the whole picture. In fact, in the early CDM literature, many scholars demonstrated worries about the prospect of a so-called 'race to the bottom', in other words the fact that, market-based character of CDM would induce host countries to set low standards for sustainable development in order to attract projects (Cosbey et al., 2005; Schneider, 2007; Sutter, 2003). These worries have been somehow confirmed. Sirohi (2007) carried out one of the few studies that directly analysed the relationship between the CDM and poverty alleviation. From a review of $65 \mathrm{CDM}$ projects, she stated that India's CDM projects have not contributed to sustainable development nor poverty reduction. Sutter and Parreño (2007) show that less than $1 \%$ of the projects registered at UNFCCC as of August 2005, contributed significantly to sustainable development. Boyd et al. (2009) studied a cross-section of ten CDM projects including landfill, fuel switch, sponge iron and renewable energy and found that significant emission reductions were gained by CDM projects. However, all projects fell short in involving local communities and in delivering direct local benefits except for one case in Peru, which illustrated direct benefits in terms of health and employment. These findings correlate with other studies that show a limited uptake of development activities by communities due to project design and procedural issues (Alexeew et al., 2010; Boyd, 2009; Brown and Corbera, 2003). Research done by Rindefjäll et al. (2011) in Chile concludes that the 'race' is not simply a structural feature of CDM, but a deliberate strategy.

More recently, there is a new insight on the potential role of some specific ST projects to act promoting carbon mitigation while generating human development in the local communities where the projects are implemented (Ventura et al., 2011b). The added value of ST versus so-called 'conventional technologies' (those with the main - if not unique - objective of maximising the production and the accumulation of capital) is the fact that in ST there is a need to include a new technology focus: the participation of the local community (Novaes and Dias, 2009). In ST, the users are encouraged to add their knowledge, values and perceptions to the development or implementation of the technology itself. This different perspective adds a non-technical or human side to the ST contributing towards to the promotion of social benefits.

\section{ST: the human side of technology}

The term ST derives from the concept of appropriate technology (AT) which was spread in the 1970s in the intermediate technology debates by the Intermediate Technology Development Group (ITDG) supported by the economist E.F. Schumacher. This ideological movement (and its manifestations) emphasises technology as people-centred, 
focusing on the use of sustainable technologies as a poverty solution and a way to promote development in developing countries. Mcrobie (1982) defined AT as technologies that meet human needs, minimising the damage to the environment and conserving local resources. The concept of AT was based on the dissemination of technologies in developing countries that do not imply large capital or advanced technology while allowing industrial and agricultural development.

The main characteristics of AT were: environment-friendly; low cost; benefit the community; and labour intensive. According to Dagnino (1976, p.86), AT can be identified by "a set of production techniques which uses the features available in some society in an optimum way thus maximising their well-being". In most cases, the technologies employed as AT were brought in from developed countries with the associated problem that development models of advanced countries could not work in countries with lower levels of economic development. Thus, a weakness in the technology transfer of AT was inbuilt. This weakness was tolerated because for a long time technology was considered to be a factor which was culturally 'neutral', without considering the changes required to introduce such technology in a given society. It is vital that the transfer processes to future users pay particular attention to the technological assimilation of communities and to the incorporation of such technology to their cultural and social habits. Technology transfer must be a comprehensive process that includes social, economic, technical and political features, with the full collaboration of future beneficiaries (Narváez, 1996).

As Dagnino et al. (2004) explain, the concept of ST is precisely an evolution from the criticism and additions made to the AT concept, avoiding the influences and perceptions of groups of researchers from the first world. Although the participation of scientists from developing countries was scant in the construction of $\mathrm{AT}$, it has been possible to incorporate cultural, social and political aspects into the discussion of a future technological model to be adopted in developing countries. It has also been possible to criticise the sociopolitical and economic contexts that until then had formed the framework for debates on science, technology and society (CTS), incorporating new visions.

However, AT defenders did not realise that "... the development of alternative technologies was only a necessary condition - and not enough - for its adoption by the social groups who wished to benefit" [Dagnino et al., (2004), p.28]. An essential human factor for the success of this type of technology - the participation of the local actors - was missing, what difficult the technology transfer and its incorporation by the communities. As Novaes and Dias (2009) explain, the AT developers were not able to design a process that could allow the generation and diffusion of alternative knowledge, through the participation of local actors.

In the $1980 \mathrm{~s}$, under the strong influence of the neoliberal system and the consequent increase in existing social and environmental problems, concern grew about technological bases which could promote more sustainable development through the knowledge of the social actors involved in the problem. Thus, the concept of ST arose. It is understood in general terms as products, techniques or methods which can be reapplied, developed and or applied in interaction with a community, which represent social transformation solutions through the sustainable use of local resources (RTS, 2011). This concept assumes an innovative proposal, considering the human factor of collective participation in the organisation, development and implementation process. 
According to Dagnino et al. (2004), the active participation of the actors is an essential ST element, without whom the ST would not occur.

Thomas (2009) defined ST as a way to design, develop, implement and manage technology oriented to solve social and environmental problems, generating social and economic dynamics of social inclusion and sustainable development. For Lassance and Pedreira (2004), ST are technologies, materials and methodological procedures which are declared and validated with a proven social impact, developed from needs so as to resolve them. A ST must always consider the local social reality and be generally linked to forms of collective organisation. They result from popular wisdom or from scientific knowledge or from the interaction between both. The Instituto de Tecnologia Social (Social Technology Institute) considers ST as a set of techniques and methods, developed and or applied in interaction with the population and appropriate for it, that represents solutions for social inclusion and improved living conditions. They try to respond through technology to the existing social problems. That is, instead of using conventional technologies, they try to be a bridge between social demands and solutions through the application of local knowledge (ITS, 2007).

As previously stated, the main object of ST is to solve social or environmental problems. Therefore, the ST can be considered a tool to promote environmental improvements in communities and regions, making use of the human side of a technology as one of the main tools to achieve it.

It is widely acknowledged by the specialised literature that the incorporation of environmental aspects in organisational processes requires the management of human factors (Jabbour et al., 2009). In this field of knowledge, these factors are "the non-technical variables that influence the incorporation of environmental aspects performance in organizations" [Jabbour et al., (2009), p.40]. The authors classify them into traditional (concerning disseminated human resource practices, such as analysis and job description, recruitment and selection, training, performance appraisal and rewards) and competitive (geared to achieving corporate strategy: team' articulation, managing organisational culture and organisational learning practices). At least in theory, attention to human factors appears to belong to the evolution stage of the organisations environmental actions. As presented by Jabbour et al. (2009), these actions can be:

1 only a reaction to environmental legislation (first evolution stage)

2 an internal integration, where the activities have as basis company performance, specially to avoid pollution (an intermediate stage)

3 a strategic stage, where the environmental activities are integrated into the business strategy, having as focus the exploitation of opportunities (for example, market access, exportation of products, among others).

The human factor in EM organisations, regardless of the maturity stage of each organisation, is different from the factors valorised in the ST adoption. However, considering the main characteristics and principles of a ST project, for this paper a correlation between some of the human factors that impact in the EM, as presented by Jabbour et al. (2009), has been developed, and the ones that should be taken into account in a ST project, as can be seen below: 
- Training: a ST is born from popular wisdom or from scientific knowledge or from the interaction between both. In all these cases, the local capability development is essential for ST results. The local actors must be prepared to take on the technology, to use it and to spread it. Participatory training, where the local community could express and use their knowledge, is one of the main techniques used.

- Performance appraisal: an ST can just be considered as one if it achieves a social or environmental transformation. Therefore, performance appraisal is indispensable to consider it a technology or not as a ST.

- Team articulation: ST success is directly linked to team articulation. Just with the local actors' true participation, or in the technology development or in its implementation, will it be possible to achieve the social or environmental transformation.

- Organisational learning practices: one of the main goals of ST is its spread, called 'reaplicação' (reapplication) in Portuguese. For this, organisational learning practices are essential, through knowledge transference between individuals and communities. The organisation responsible for specific ST reapplication must to organise meetings and other tools to encourage experience and knowledge exchanges between local present and future ST users.

\subsection{The relationship between ST and climate change: an overview in the State of Bahia, Brazil}

Until this moment, the solutions that have been promoted by the climate environmental governance at international and even national levels has been strongly guided by market solutions, through projects carried out by private companies. Little attention has been given to projects developed by non-profit organisations that have been designing solutions to a given problem or social environment and that is also contributing to climate change mitigation.

However, surveys conducted in recent years suggest that ST developed in Brazil, and more specifically in the State of Bahia, have a dual potential. Thus, while contributing to, in a participatory way, solve a local problem; bring benefits to the environmental issue, through actions that allow the GHG emission reductions (Santos, 2011; Trujillo, 2011; Ventura et al., 2011b).

In order to clarify the potential of ST on the reduction of GHG, a document analysis of the identified ST in the State of Bahia was performed (Ventura et al., 2011a). Thirty-one ST were analysed based on the mapping done by NACIT (2010). The review aimed to identify whether the ST incorporated in its projects:

1 use of renewable raw materials

2 replacement of the energy matrix

3 more rational and efficient use of water and energy

4 less-intensive GHG technologies

5 deforestation reduction

6 more efficient farming practices 


\section{7 use of degraded lands}

8 waste reduction, reuse and recycling.

Results showed that 12 of the $31 \mathrm{ST}$ analysed have elements to contribute to climate change mitigation. In addition, five out of the 12 identified ST with mitigation potential where found to generate relevant benefits to the living conditions of the local communities where the technologies were being developed, among them the "efficient stoves'. A description of each of the five ST is given below, with more emphasis on 'efficient stoves', the object of this study. Table 1 summarises the main characteristics of the selected ST in regards to its potential to climate change mitigation and to benefit the local communities:

1 Biodigestor. This is a technology designed to be used collectively in productive activities related to settlements and other communitarian areas. It uses organic waste matter produced by animals (especially goats and sheep) for the production of biogas, used as an energy source in homes, replacing cooking gas or firewood. The wastes are also used as bio fertilisers to replace chemicals as nutrients. The TS was originally developed by Winrock Institute in partnership with Universidade do Estado da Bahia (UNEB), and enjoyed the support of the Conselho Nacional de Desenvolvimento Científico - CNPq (National Council of Scientific Development) and United States Agency for international development (USAID).

2 Produção Agroecológica Irrigada - PAIS (irrigated agro ecological production). The technology can be used in place of agribusiness practices. It is an experience of supporting family farms, with the use of sustainable farming techniques, without the use of toxic products in order to preserve the environment. The main techniques used by the PAIS system are:

- drip irrigation system, using gravity

- integration of poultry farming, small animals, goats or cattle, according to local or regional vocations

- the waste produced by that animals are the raw material for production of compost natural fertiliser

- diversification of production for maximum recovery of soil nutrients and aid in the control of pests and diseases

- agroecological backyards to add to the family income through the production of fruits and vegetables and at the same time of pasture for small animals.

The PAIS has been pervasive in 12 Brazilian states.

3 Bomba D'Água Popular - BAP (popular water pump). This technology has emerged as a solution to give operation to wells drilled in the 1980s in areas of underground crystalline, but low water. The pump, built in lateral position to the pit, guarantee water throughout the year, even in times of increased scarcity of rainfall. The water is used for the household communities, is acceptable quantity and quality for irrigation and agricultural properties, and cattle rearing. It can work 24 hours per day at no cost, because it is driven by human action. Its maintenance is extremely simple, done by local producers themselves, which are duly empowered by the project. BAP has been incorporated into the technologies of semiarid coexistence. 
4 Agricultura Orgânica Irrigada (irrigated organic agriculture). The project, posterior renamed as 'Adapta Sertão' (Semiarid Adaptation), is being developed by Rede Pintadas, with the financial support by SouthSouthNorth international network, by State of Bahia science and technology agency, by an state bank and by two no governmental organisations from Italy and Germany. The technology consists of photovoltaic panels which use solar energy to trigger a pump that takes water to a tank, from where it leaves in pipes to an irrigated system of agriculture, using drip techniques or hydroponics. Farmers take advantage of forage to feed the animals and produce better vegetables. The purpose of the technology is to ensure food security and income generation based on small and medium-sized agricultural production, without destroying the local ecosystem. The project was considered good practice by Wisions Organization, in 2006, and by Dubai Award UN-Habitat, in 2008. It also received the 2008 SEDD award, chosen from among more than 400 projects in the world, as one of the five practices that deserve to be worked on a larger scale.

5 Fogões Eficientes (efficient stoves). The first efficient stoves project was implemented in 2002, with the support by Brazilian Service of Support for Micro and Small Enterprises (SEBRAE) for local artisans. Another partner, Aghenda NGO, donated three 'efficient stoves' to the community. The association of artisans use the stoves in the straw dyeing process used to manufacture handmade objects, replacing traditional rudimentary stoves that use large amount of fire wood from native species of trees. Domestic smoke caused by burning firewood represents a threat to the quality of life in the countryside and causes various respiratory diseases. According to the World Health Organization, an estimated 1.6 million people die every year due to diseases caused by burning firewood. The positive environmental contribution from the stoves was originally overshadowed by structural problems (the metal plates started to break into pieces). The supplier, from Minas Gerais, another Brazilian state, suggested that it was because of the difference in combustion temperature of the native wood from the semi-arid region. Eventually, technical problems were solved confirming that ST must necessarily be adapted to the local circumstances.

Table 1 Main characteristics of the selected ST

\begin{tabular}{|c|c|c|c|}
\hline Type of ST & $\begin{array}{c}\text { Climate change } \\
\text { mitigation }\end{array}$ & Benefits to the local communities & Limitations \\
\hline Biodigester & $\begin{array}{l}\text { Recovery of } \\
\text { methane in an } \\
\text { efficient } \\
\text { manner for } \\
\text { the generation } \\
\text { of renewable } \\
\text { energy. }\end{array}$ & $\begin{array}{l}\text { Decreasing fuel oil } \\
\text { investments } \\
\text { - Reducing exposure to } \\
\text { nuisance odors } \\
\text { - Building capacity in biogas } \\
\text { systems, allowing for more } \\
\text { widespread replication } \\
\text { - Improvement in food } \\
\text { production, without additional } \\
\text { costs (due to the fertilisers) }\end{array}$ & $\begin{array}{l}\text { - Risk of technological } \\
\text { dependence } \\
\text { - Appropriate training } \\
\text { to use and maintain } \\
\text { the biodigester needs } \\
\text { to be accomplished }\end{array}$ \\
\hline
\end{tabular}

Source: Adaptation of Ventura et al. (2011a) 
Table 1 Main characteristics of the selected ST (continued)

\begin{tabular}{|c|c|c|c|}
\hline Type of $S T$ & $\begin{array}{c}\text { Climate change } \\
\text { mitigation }\end{array}$ & Benefits to the local communities & Limitations \\
\hline $\begin{array}{l}\text { Irrigated } \\
\text { agro } \\
\text { ecological } \\
\text { production }\end{array}$ & $\begin{array}{l}\text { - Energy use } \\
\text { reduction } \\
\text { - Elimination } \\
\text { of chemical } \\
\text { fertilisers and } \\
\text { pesticides }\end{array}$ & $\begin{array}{l}\text { - Strongly reduction of external } \\
\text { suppliers and of production } \\
\text { costs } \\
\text { - Improve in income generation } \\
\text { - Food security } \\
\text { - Easy implementation and } \\
\text { maintenance }\end{array}$ & $\begin{array}{l}\text { - The project needs to } \\
\text { be scaled up to really } \\
\text { impact the local } \\
\text { economy }\end{array}$ \\
\hline $\begin{array}{l}\text { Popular } \\
\text { water pump }\end{array}$ & $\begin{array}{l}\text { - Energy use } \\
\text { reduction as } \\
\text { the pump is } \\
\text { manually } \\
\text { used }\end{array}$ & $\begin{array}{l}\text { - Water availability for watering } \\
\text { animals and food production } \\
\text { - Easy maintenance by local } \\
\text { suppliers }\end{array}$ & $\begin{array}{l}\text { - Risk of technological } \\
\text { dependence } \\
\text { - Isolated households } \\
\text { are not beneficiaries } \\
\text { of this type of ST } \\
\text { since it is necessary a } \\
\text { minimum number of } \\
\text { families to make } \\
\text { technology } \\
\text { sustainable }\end{array}$ \\
\hline $\begin{array}{l}\text { Irrigated } \\
\text { organic } \\
\text { agriculture }\end{array}$ & $\begin{array}{l}\text { - Use of } \\
\text { renewable } \\
\text { energy }\end{array}$ & $\begin{array}{l}\text { - Food security } \\
\text { - Improvement in food } \\
\text { production } \\
\text { - Activation of the local } \\
\text { economy } \\
\text { - Easy implementation and } \\
\text { maintenance }\end{array}$ & $\begin{array}{l}\text { - A water pump is still } \\
\text { necessary. Water } \\
\text { pump traditionally } \\
\text { relies on the oil. } \\
\text { - The project needs to } \\
\text { be scaled up to really } \\
\text { impact the local } \\
\text { economy. }\end{array}$ \\
\hline $\begin{array}{l}\text { Efficient } \\
\text { stoves }\end{array}$ & $\begin{array}{l}\text { - Reducing the } \\
\text { consumption } \\
\text { of non- } \\
\text { renewable } \\
\text { biomass } \\
\text { - Energy } \\
\text { efficient } \\
\text { - Reducing } \\
\text { pressure on } \\
\text { the natural } \\
\text { forests and } \\
\text { thus reduce } \\
\text { deforestation }\end{array}$ & $\begin{array}{l}\text { - Contributing to poverty } \\
\text { alleviation by reducing } \\
\text { household expenditure on } \\
\text { wood purchases } \\
\text { - Improving indoor air quality } \\
\text { in homes, generating health } \\
\text { benefits for the community, } \\
\text { especially for women who do } \\
\text { most of the cooking } \\
\text { - Reducing the time spent } \\
\text { collecting firewood, a task } \\
\text { usually carried out by women } \\
\text { and children collection, } \\
\text { thereby freeing up their time } \\
\text { for social, domestic and } \\
\text { educational activities }\end{array}$ & $\begin{array}{l}\text { - Technical experts are } \\
\text { needed for the design } \\
\text { and development of } \\
\text { the technology which } \\
\text { have to be adapted to } \\
\text { the local context and } \\
\text { cannot directly be } \\
\text { imported from other } \\
\text { locations. }\end{array}$ \\
\hline
\end{tabular}

Source: Adaptation of Ventura et al. (2011a)

Agendha is preparing itself to introduce new designed stoves in the community, following the successful TS carried out by IDER - Instituto de Desenvolvimento 
Sustentável e Energias Renováveis (Institute of Sustainable Development and Renewable Energies) in Ceará. Following this successful story, other stoves projects are being widespread around Brazil and some of them start to take into consideration the possibility of selling carbon credits to guarantee their sustainability; as example the one developed by Instituto Perene in Bahia, object of this case study.

\section{Methodology}

The approach described hereafter discusses the potential benefits (both to promote human development and to improve the public image of a company) of these EM initiatives that aim to offset carbon emissions through mitigation carbon projects in vulnerable communities. This analysis claims in no way to provide an absolute evaluation of each project contribution to human development as such. Rather, it focuses on the human side of the project design and implementation to evaluate how these 'non-technical' factors are affecting the final results.

The research uses a case study analysis of a Brazilian company, Natura, offsetting its emissions through the Brazilian voluntary carbon market. The efficient cook stoves project was primarily selected because the technology used is a ST. ST are supposed to take into consideration human factors more than conventional ones. Furthermore, in 2011 the selected project received the 'Special Achievement Award' of the Environmental Protection Agency (EPA), from USA, due to the 'excellent performance in monitoring and community engagement.

Table 2 Proposed pro-poor co-benefit indicators for mitigation projects

\begin{tabular}{|c|c|c|}
\hline Dimension & Criterion & Indicator \\
\hline \multirow[t]{7}{*}{ Empowerment } & $\begin{array}{l}\text { Development/diffusion } \\
\text { of local/imported } \\
\text { technology }\end{array}$ & $\begin{array}{l}\text { - Development, use, improvement and/or diffusion } \\
\text { of a new local or international technology } \\
\text { - Collaboration with universities or research } \\
\text { centres for the development, use, improvement } \\
\text { and/or diffusion of the new local or international } \\
\text { technology }\end{array}$ \\
\hline & $\begin{array}{l}\text { Engagement of local } \\
\text { population and }\end{array}$ & $\begin{array}{l}\text { - Adequate mitigation measures proposed by the } \\
\text { project developer on stakeholder concerns }\end{array}$ \\
\hline & $\begin{array}{l}\text { generation of social } \\
\text { capital }\end{array}$ & $\begin{array}{l}\text { - Stakeholder perception of the project activity } \\
\text { contribution to sustainable development of } \\
\text { community/acceptance of the project }\end{array}$ \\
\hline & & - Increased awareness of environmental issues \\
\hline & & - Professional training of local workers \\
\hline & & - Migration reduction \\
\hline & $\begin{array}{l}\text { Empowerment of } \\
\text { vulnerable groups }\end{array}$ & $\begin{array}{l}\text { Improvements of vulnerable groups (women, } \\
\text { youth, children and people with disabilities) in } \\
\text { society: in access to education and training; } \\
\text { through positive discrimination policies for the } \\
\text { employment and/or increasing spare time }\end{array}$ \\
\hline
\end{tabular}


The analysis method for the case study is based on the sustainable and empowerment framework (S\&E). This framework was introduced by Fernández et al. (2011) to evaluate the contribution of CDM projects to human development in host countries. The S\&E proposes four dimensions for the evaluation of the human development impact: economic, social, environmental and empowerment. For this paper, just the empowerment dimension is used because it is the dimension which is more directly related to the human side of the projects. Table 2 presents the proposed indicators defined by the S\&E for the empowerment dimension.

To complement the project evaluation through the S\&E criteria and indicators, the four dimensions of organisations EM human factor that are correlated to ST are also qualitatively assessed: training, performance appraisal, articulation of teams, and organisational learning practices.

\section{5 'Efficient stoves' case study as win-win strategy}

\subsection{Introducing the case study: Natura carbon neutral programme}

Natura is a Brazilian company which produces personal hygiene products, perfumery and cosmetics. The focus of the current case study is a Natura's programme called 'Natura Carbono Neutro' (carbon neutral Natura). The programme, which has been functioning since 2007, aims to "quantify, reduce and compensate greenhouse gases emission in the production chain, from natural resource and material extraction, through internal processes and product transportation, to its disposal" [Natura, (2011), p.2].

The carbon neutral programme is divided into three steps (Natura, 2012):

1 Inventory (measurement and emission register): carried out in all the production chain. Emission measurement has been done from before the beginning of the carbon neutral programme, according to the Greenhouse Gas Protocol Initiative (GHG Protocol) and to the ABNT NBR ISO 14064-1 ${ }^{1}$ guidelines.

2 Reduction (actions and processes to reduce emissions): the commitment is to reduce absolute emissions by $10 \%$ by 2012 , and to reduce emissions by in $33 \%$ per kilo of the product billed by 2013 .

3 Offset (support for projects to offset the emissions that are unavoidable): the carbon neutral programme stipulates that everything that cannot be reduced, will be offset by the acquisition of carbon credit, through projects chosen in a biennial open announcement, now in its third edition.

The offset step is the focus of this research. The programme stipulates that the offsetting projects must have 'evident socio and environmental benefits' [Natura, (2011), p.2], that are 'locally relevant' [Natura, (2012), p.29] and will be select through public announcement. The projects must have a baseline and monitoring already approved in four different projects categories:

- Energy: projects related to eco-efficiency.

- Forests: projects involving forestation, reforestation and agroforestry systems. 
- REDD + (Deforestation and forest degradation reduction): projects fort environmental conservation and preservation in areas under pressure from deforestation or degradation.

- Other: projects that present practices, technologies and differentiated solutions in the fight against global warming and that do not fit into the other categories (Natura, 2011).

\subsection{The human factors in the 'efficient stoves' project}

As mentioned above, the 'efficient stoves' is one of Natura's compensation projects, selected the 2008 and in the 2009/2010 editions, to promote the replacement of, 1,000 and 5,000 rudimentary stoves, respectively, in the Recôncavo region of Bahia. The baseline and monitoring are done through the Gold Standard (2012) method, "an award winning certification standard for carbon mitigation projects and is recognised internationally as the benchmark for quality and rigor in both the compliance and voluntary carbon markets". The certification aims to ensure that the projects demonstrate real and permanent GHG reductions and promote sustainable development benefits in local communities. The benefits must be measured, reported and verified.

The "Gold Standard Local Stakeholder Consultation Report: Efficient Stoves in the Bahia Recôncavo" assures that the type of project activity is an "end-use energy efficiency improvement', which will reduce the amount of energy required for domestic cooking in rural households, being classified as "Improved distributed heating and cooking devices (e.g., stoves), and distributed micro-scale electricity generation units", in a micro scale level (Gold Standard, 2009).

The summary of the S\&E application, considering the indicators directly related to the human resources management factors in particular, is presented in the Table 3.

As seen in Table 3, as well as other more the typical ST human factors that were observed in the 'Efficient Stoves' offsetting project (collective participation in ST construction and implementation, and consideration of the local reality, though the community knowledge of the social and environmental problem to be solved), it was possible to notice that some of the human factors usually associated to the EM programmes, presented in the theory section, are also present.

- Training: the women from the community were trained by other women, also from the local area, to use the technology. A special group of women were firstly selected to receive training to help the group to comprehend the specifics of the technology. Besides this, all the community groups were invited to take part in meetings where the technology was explained, and the social and environmental benefits were shown.

- Performance appraisal: according to the interviewed people, the technology really achieved excellent performance, representing a real solution for the health problems caused by the smoke. According to Instituto Perene, the ST management, Gold Standard monitoring system was able to confirm the GHG reduction promoted by the use of the technology. 
- Team articulation: the local actors articulated themselves to organise the explanatory and training meetings. They also organised themselves to spread the introduction of the technology among local communities.

- Organisational learning practices: the second edition ST. Some important learning was incorporated into the technology in the new stoves that were constructed. One example was the introduction of a different kind of chimney, because, as the women responsible for the monitoring found, the ones that were installed close to the sea started to rust. The material for the new chimneys was discussed with the local users, in meetings that were held among people from different communities, to exchange experiences and knowledge about the ST.

Table 3 Human factors and human development indicators in the 'efficient stoves' project

\begin{tabular}{l} 
Human development indicator \\
\hline Development, use, \\
improvement and/or diffusion \\
of a new local or international \\
technology
\end{tabular}

Collaboration with universities or research centres for the development, use, improvement and/or diffusion of the new local or international technology

Adequate mitigation measures proposed by the project developer on stakeholder concerns
Human factor in field observations and interviews results Before the project development, the rural families in Recôncavo region still mostly used rudimentary stoves that use a large amount of native firewood and produce smoke inside homes causing health problems. During the project development, the community were able to collaborate with the design of the technology. Even after the elaboration of five prototypes, and the technology dissemination (construction in various municipalities), the local users could give their opinion about new improvements to be done. The accumulated knowledge from the women at the localities permitted that the constructed stoves were appropriated by the community. The ecological or eco-efficient stoves are being used in many African countries as a way to mitigate GHG gases.

The project was designed with the collaboration of Approveche Institute, a technology centre specialised in technologies for the least favoured people in the USA. The American researchers went to Bahia to develop the stove technology in partnership with the local community. Five prototypes were made, in collaborative construction in a three day workshop, until the best one was designed, in the community's opinion. This way, the transfer of technology could occur in full. After the research centre visit, the local masons were prepared to construct the stoves in the way that it was considered acceptable by the local users. The technology was socially constructed with a sum of knowledge

The project involved the introduction of a new technology that was designed with the participation of local actors. They could give opinions about the size, the height and the format. Because of this human factor, the technology was really adopted in the communities. According to the respondents, there were more people interested in receiving the stove than the resource capacity to build them.

The final users signed a contract giving the carbon credit rights to Instituto Perene. Their pride in participating in a climate change mitigation and environmental solution was noticeable. 
Table 3 Human factors and human development indicators in the 'efficient stoves' project (continued)

\begin{tabular}{|c|c|}
\hline Human development indicator & Human factor in field observations and interviews results \\
\hline $\begin{array}{l}\text { Stakeholder perception of the } \\
\text { project activity to improve } \\
\text { living conditions of } \\
\text { community/ acceptance of the } \\
\text { project }\end{array}$ & $\begin{array}{l}\text { The stakeholders consulted firmly believe that their lives } \\
\text { improved considerably with the installation of the stoves. They } \\
\text { mentioned improvements in health quality (reduction in } \\
\text { respiratory problems, inexistence of eye irritation) and in the } \\
\text { reduced efforts to obtain firewood (reduction of up to } 60 \% \text { in } \\
\text { fire wood use). They also recognise the role of Natura in } \\
\text { helping them to acquire the technology, viewing the company } \\
\text { as one of the elements responsible for improvement in their } \\
\text { living conditions. }\end{array}$ \\
\hline $\begin{array}{l}\text { Increased awareness of } \\
\text { environmental issues }\end{array}$ & $\begin{array}{l}\text { The local stakeholders mentioned that, after the project, they } \\
\text { are helping the environment because they are using much less } \\
\text { firewood, reducing deforestation. They also mentioned GHG } \\
\text { reduction, and its consequent positive impacts on climate } \\
\text { change. }\end{array}$ \\
\hline $\begin{array}{l}\text { Professional training of local } \\
\text { workers }\end{array}$ & $\begin{array}{l}\text { All the construction of the stoves was done by local builders, } \\
\text { specially trained for the activity. In addition, some local } \\
\text { women were trained to explain the project to the community, } \\
\text { to train the community to use the technology and to follow the } \\
\text { stove installation, and to collect the final users' opinion. The } \\
\text { interviewed workers stated that they were proud and satisfied } \\
\text { to be part of the project, and to be acquiring new abilities. }\end{array}$ \\
\hline Migration reduction & $\begin{array}{l}\text { As all the materials purchasing was done from local suppliers, } \\
\text { the economy in the region was stimulated. Two of the } \\
\text { respondents stated that if there had not been the project, they } \\
\text { would have had to migrate to other parts of the country. }\end{array}$ \\
\hline $\begin{array}{l}\text { Improvements to health, } \\
\text { safety and welfare of local } \\
\text { people through a reduction in } \\
\text { exposure to factors impacting } \\
\text { health and safety }\end{array}$ & $\begin{array}{l}\text { This was one of the main improvements promoted by the } \\
\text { project. With the new stoves, the women confirmed the totally } \\
\text { exclusion of smoke in the kitchen, and, as consequence, the } \\
\text { elimination of respiratory diseases and eyes irritation. In } \\
\text { addition, they emphasised the fact that they do not smell of } \\
\text { smoke anymore, resulting in a marked increase in self-esteem. } \\
\text { Some women also mentioned their pride with their kitchen } \\
\text { now, much cleaner and more beautiful, cleaner appearance of } \\
\text { their cooking utensils. }\end{array}$ \\
\hline $\begin{array}{l}\text { Improvements of vulnerable } \\
\text { groups (women, youths, } \\
\text { children and people with } \\
\text { disabilities) in society: in } \\
\text { access to education and } \\
\text { training; through positive } \\
\text { discrimination policies for the } \\
\text { employment and/or increasing } \\
\text { spare time }\end{array}$ & $\begin{array}{l}\text { Women are mostly responsible for cooking in most of the } \\
\text { world, and this is no different in the Recôncavo region. They } \\
\text { are also responsible for wood collection. Consequently there } \\
\text { was a double improvement in their lives: health, safer cooking, } \\
\text { and work, increasing time for other activities. }\end{array}$ \\
\hline
\end{tabular}

Source: Own elaboration (2012) 


\section{Conclusions}

Carbon management has gradually gained attention within the overall EM and the CRS agendas of corporations. This article provides some evidence about the role of the human side and/or the human factors in the implementation of offsetting programmes in relation to their contribution to human development.

The research was firstly motivated by findings that suggest that the CDM projects are not contributing enough to generate social co-benefits, and the fact that voluntary carbon markets seem to be a possibility for this generation, as companies are increasingly valuing projects that bring additional social contributions.

The 'efficient stoves' case study shows that the human factor in the collective participation in ST mitigation project implementation has led to a better image of the company along with human development co-benefits.

Evidence suggests that NGO involvement in the implementation plays a key role in increasing positive results although further study is necessary. It seems that the involvement of external, non-profit organisations, could focus results on social benefits. The correlation between the NGO selection as partnership and the maturity stage of the company in EM's results should be investigated.

The Natura case study also suggests that that the fact that Voluntary Carbon markets are flexible can effectively contribute to human development if an AT is selected.

The main finding from the case study is the confirmation that through the use of ST, offsetting projects contribute more significantly to obtain co-benefits. This is because of the emphasis on human factors, such as local community participation, team articulation and performance appraisal. Future research should contemplate the extension of this study to more case studies to provide and systematise useful knowledge for other private companies that want to develop projects to become carbon neutral while contributing to social benefits and improving their image for society.

\section{Acknowledgements}

This study was partially funded by the Technical University of Madrid under its 11th funding programme for university cooperation actions for development (ref. 25).

\section{References}

Alexeew, J., Bergset, L., Meyer, K., Peterson, J., Schneider, L. and Unger, C. (2010) 'An analysis of the relationship between the additionality of CDM projects and their contribution to sustainable development', International Environmental Agreements: Politics, Law and Economics, Vol. 10, No. 3, pp.233-248.

Ashford, L., Mountain, R., Baczko, S., Oden, R., Calvert J., O'Keeffe S., Davey, C., Stuart, G., Gutmann, S., Wheeland M., Herrera, T., Young, S. and Lazo, B. (2009) ${ }^{\circ}$ The Carbon Management and Offsetting Trends Survey Results 2009. EcoSecurities, ClimateBiz and Baker $\&$ McKenzie LLP, [online] http://www.ecosecurities.com/Standalone/Carbon_Management_and_Offsetting_Trends_Surv ey_Results_2009/default.aspx (accessed 8 July 2010). 
Boyd, E., Hultman, N., Roberts, J.T., Corbera, E., Cole, J., Bozmokski, A., Ebeling, J., Tippman, R., Manna, P., Brown, K. and Liverman, D.M. (2009) 'Reforming the CDM for sustainable development: lessons learned and policy futures', Environmental Science \& Policy, Vol. 12, No. 7, pp.820-831.

Brown, K. and Corbera, E. (2003) 'A multi-criteria assessment framework for carbon- mitigation projects: putting 'development' in the centre of decision-making', Tyndall Centre Working Paper 29.

Chapple, A. (2008) 'Making the voluntary carbon market work for the poor', Forum for the Future, London, available at http://www.forumforthefuture.org/sites/default/files/project/downloads/making-voluntarycarbon-markets-work-final.pdf (acessed on 27 November 2012).

Cosbey, A., Parry, J-E., Browne, J., Babu, Y.D., Bhandari, P., Drexhage, J. and Murphy, D. (2005) 'Realizing the development dividend: making the CDM work for developing countries', Phase 1 Report - Prepublication Version, International Institute for Sustainable Development (IISD), pp.1-72.

Dagnino, R. (1976) 'Tecnologia apropriada: uma alternativa?', Unpublished Master thesis, Departamento de Economia, Universidade de Brasília, Brasilia, Brazil.

Dagnino, R., Brandão, F.C. and Novaes, H.T.N. (2004) 'Sobre o marco analítico-conceitual da tecnologia social', in Lassance, A. and Pedreira, S. (Eds.): Tecnologia social: uma estratégia para o desenvolvimento, Fundação Banco do Brasil, Rio de Janeiro.

Fernández, L., Lumbreras, J., Borge, R. and Cobo-Benita, J.R. (2011) 'Exploring co-benefits of clean development mechanism (CDM) projects', Paper presented at the Conference on Sustainable Development, Shangai, October.

Gold Standard (2009) 'Gold Standard Local Stakeholder Consultation Report: Efficient Stoves in the Bahian Recôncavo', Gold Standard Passport version 2.1 July 2009

Gold Standard (2012) 'Who we are', available at http://www.cdmgoldstandard.org/about-us/whowe-are (accessed on 5 January 2012).

Instituto de Tecnologia Social (ITS) (2007) 'Conhecimento e Cidadania 1: Tecnologia Social', available at

http://www.itsbrasil.org.br/sites/default/files/Digite_o_texto/Caderno_Serie_Conhecimento_e _Cidadania_-_Tecnologia_social_-_1.pdf (accessed on 19 July 2010).

Jabbour, C.J.C., Santos, F.C.A. and Jabbour, A.B.L. de S. (2009) 'A importância dos fatores humanos no desenvolvimento de produtos com elevado desempenho ambiental: estudos de caso', RAM - Revista de Administração Mackenzie, July/August, Vol. 10, No. 4, pp.32-56, São PAULO, SP.

Kollmuss, A., Zink, H. and Polycarp, C. (2008) 'Making sense of the voluntary carbon market. a comparison of carbon offset standards', Published by WWF Germany, available at assets.panda.org/downloads/vcm_report_final.pdf (acessed on 15 October 2011).

Lassance, A. and Pedreira, S. (2004) Tecnologia social: uma estratégia para o desenvolvimento, Fundação Banco do Brasil, Rio de Janeiro.

Mcrobie, G. (1982) The Community's Role in Appropriate Technology, Hildegarde Hannum, New York.

Muller, A. (2008) 'Risk management in the clean development mechanism (CDM) - the potential of sustainability labels', Economics and Management of Climate Change: Risks, Mitigation and Adaptation, pp.193-207, Springer, NewYork.

Narváez, J. (1996) Tecnologías apropiadas para el desarrollo sostenible, ITACAB, Peru.

Natura (2011) 'Edital Carbono Neutro 2011/12: Perguntas Frequentes', available at http://scf.natura.net (acessed in 28 January 2012).

Natura (2012) 'Programa Carbono Neutro', available at http://scf.natura.net/Conteudo/Default.aspx?MenuStructure=4\&MenuItem=29 (accessed on 31 January 2012). 
Novaes, H.T. and Dias, R. (2009) 'Contribuições ao Marco Analítico-Conceitual da Tecnologia Social', in Dagnino, R.P. (Ed.): Tecnologia social: ferramenta para construir outra sociedade, IG/Unicamp, Campinas.

Núcleo de Política e Administração em Ciência e Tecnologia - NACIT (2010) Relatório de pesquisa do projeto Mapeamento da Inovação no Estado da Bahia: subprojeto Mapeamento e Caracterização das Tecnologias Sociais. Salvador: Universidade Federal da Bahia.

Nussbaumer, P. (2009) 'On the contribution of labelled Certified Emission Reductions to sustainable development: a multi-criteria evaluation of CDM projects', Energy Policy, Vol. 37, No. 1, pp.91-101.

Olsen, K.H. (2007) 'The clean development mechanism's contribution to sustainable development: a review of the literature', Climatic Change, Vol. 84, No. 1, pp.59-73.

Rede de Tecnologia Social (RTS) (2011) 'Conceito de tecnologia social', available at http://www.rts.org.br/. (accessed on 20 July 2011).

Rindefjäll, T., Lund, E. and Stripple, J. (2011) 'Wine, fruit, and emission reductions: the CDM as development strategy in Chile', Int. Environ. Agreements, Vol. 11, No. 1, pp.7-22, DOI $10.1007 / \mathrm{s} 10784-011-9151-0$.

Santos, J. (2011) 'Estratégias de convivência para a conservação dos recursos naturais e mitigação dos efeitos da desertificação no semiárido', in Lima, R.d.C.C., Cavalcante, A.d.M.B. and Perez-Marin, A.M. (Eds.): Ministério de Ciência e Tecnologia (MCT), Desertificação e Mudanças Climáticas no Semiárido Brasileiro, INSA-PB, Campina Grande

Schneider, L. (2007) 'Is the CDM fulfilling its environmental and sustainable development objective? An evaluation of the CDM and options for improvement', World Wildlife Fund, Berlin, available at http://www.oeko.de/oekodoc/622/2007-162-en.pdf (acessed on 10 January 2012).

Schneider, L. (2008) 'A clean development mechanism (CDM) with atmospheric benefits for a post-2012 climate regime', World Wildlife Fund, Berlin, available at http://www.oeko.de/oekodoc/779/2008-227-en.pdf (acessed on 10 January 2012).

Sirohi, S. (2007) 'CDM: is it a 'win-win' strategy for rural poverty alleviation in India?', Climatic Change, Vol. 84, No. 1, pp.91-110.

Subbarao, S. and Lloyd, B. (2011) 'Can the clean development mechanism (CDM) deliver?', Energy Policy, Vol. 39, No. 3, pp.1600-1611.

Sutter, C. (2003) Sustainability Check-Up for CDM Projects, Wissenschaftlicher Verlag, Berlin.

Sutter, C. and Parreño, J.C. (2007) 'Does the current clean development mechanism (CDM) deliver its sustainable development claim? An analysis of officially registered CDM projects', Climatic Change, Vol. 84, No. 1, pp.75-90.

Tayab, N. (2006) 'Exploring the market for voluntary carbon offsets', International Institute for Environment and Development, available at http://pubs.iied.org/pdfs/G00268.pdf (accessed on 15 January 2012).

Thomas, H. (2009) 'Tecnologias para a inclusão social e políticas públicas na América Latina', in Oterloo, A. (Ed.): Tecnologia social: caminhos para a sustentabilidade, Rede de Tecnologia Social (RTS), Brasilia.

Trujillo, R.H. (2011) 'Diseño De Una Herramienta Para La Estimación Del Impacto Sobre El Desarrollo Humano De Tecnologías Sociales De Mitigación Y Adaptación Al Cambio Climático', Unpublished graduation research final work, Engeniaría Industrial. Universidad Politécnica de Madrid (UPM), Spain.

Umamaheswaran, K. and Michaelowa, A. (2006) 'Additionality and sustainable development issues regarding CDM projects in energy efficiency sector', Hamburgisches Welt-WirtschaftsArchiv (HWWA), HWWA Discussion Paper 346, ISSN: 1616-4814.

Ventura, A.C., Andrade, J.C.S. and Almeida, A.C.A.d. (2011a) 'Soluções locais para problemas globais: análise de possíveis contribuições das tecnologias sociais para a mitigação do aquecimento global', Revista Ciências Administrativas (UNIFOR), Vol. 17, No. 3, pp. $768 / 6-795$ 
Ventura, A.C., Fernandez, L. and Trujillo, R. (2011b) 'Potencial das tecnologias sociais para o enfrentamento das mudanças climáticas e para a promoção do desenvolvimento humano: um olhar sobre o semiárido baiano', Revista Bahia Análise \& Dados, Especial: Mudanças Climáticas, Vol. 21, No. 4, pp.915-931, Superintendência de Estudos Econômicos e Sociais da Bahia, Salvador.

\section{Notes}

1 Lays down rules for the design, development, management and development of greenhouse gas inventories 